\title{
Shinella granuli gen. nov., sp. nov., and proposal of the reclassification of Zoogloea ramigera ATCC 19623 as Shinella zoogloeoides sp. nov.
}

\author{
Dong-Shan An, Wan-Taek Im, Hee-Chan Yang and Sung-Taik Lee \\ Department of Biological Sciences, Korea Advanced Institute of Science and Technology \\ (KAIST), Guseong-dong 373-1, Yuseong-gu, Daejeon 305-701, Republic of Korea
}

Correspondence

Sung-Taik Lee

e_stlee@kaist.ac.kr

\begin{abstract}
The taxonomic position of a novel bacterial strain, $\mathrm{ChO6}^{\top}$, isolated from an upflow anaerobic sludge blanket reactor was determined. Strain $\mathrm{ChO6}^{\top}$ was Gram-negative, aerobic, motile and oxidase- and catalase-positive. A comparative 16S rRNA gene sequence analysis showed a clear affiliation of strain $\mathrm{ChO}^{\top}$ to the Alphaproteobacteria and it was most closely related to Zoogloea ramigera ATCC 19623 and Mycoplana dimorpha IAM $13154^{\top}$ (97.9 and 96.3\% sequence similarity, respectively). The major respiratory quinone was $\mathrm{Q}-10$ and the predominant fatty acids were $\mathrm{C}_{16: 0}, 3-\mathrm{OH} \mathrm{C}_{16: 0}, \mathrm{C}_{18: 0}, \mathrm{C}_{19: 0}$ cyclo $\omega 8 \mathrm{c}$ and summed feature $7\left(\mathrm{C}_{18: 1} \omega 7 \mathrm{c} / \omega 9 \mathrm{t} /\right.$ $\left.\omega 12 t, \mathrm{C}_{18: 1} \omega 7 \mathrm{c} / \omega 9 \mathrm{c} / \omega 12 t\right)$. On the basis of phenotypic, chemotaxonomic and phylogenetic characteristics, the novel isolate was assigned to a new genus, Shinella gen. nov., as Shinella granuli gen. nov., sp. nov. (type strain $\mathrm{ChO6}^{\top}=\mathrm{KCTC} 12237^{\top}=\mathrm{JCM} 13254^{\top}$ ). It is proposed that Zoogloea ramigera ATCC 19623 is reclassified into the novel genus Shinella as Shinella zoogloeoides sp. nov. (type strain ATCC $19623^{\top}=$ IAM $12669^{\top}=\mathrm{I}-16-\mathrm{M}^{\top}$ ).
\end{abstract}

In the course of a study on the culturable aerobic bacterial community in granules from an upflow anaerobic sludge blanket (UASB) reactor, a large number of novel bacterial strains were isolated (Bae et al., 2005; La et al., 2005). One of these isolates, designated $\mathrm{Ch}_{06}{ }^{\mathrm{T}}$, occupied a distinct phylogenetic lineage with the previously described strain Zoogloea ramigera ATCC 19623 (=IAM 12669) within the 'Rhizobiaceae group' of the Alphaproteobacteria on the basis of $16 \mathrm{~S}$ RNA gene sequence analysis.

Zoogloea ramigera, the type species of the genus Zoogloea (Unz, 1984), is defined as a Gram-negative, obligately aerobic, chemo-organotrophic, non-spore-forming, rod-shaped bacterium that produces a characteristic gelatinous matrix of finger-like projections, the so-called 'zoogloeal matrix' (Unz, 1984; Dugan et al., 1992). Three strains of $Z$. ramigera are well-known through a number of experimental studies: the type strain ATCC $19544^{\mathrm{T}}\left(=106^{\mathrm{T}}\right.$; Unz, 1971), ATCC 19623 (=I-16-M; Crabtree \& McCoy, 1967) and ATCC 25935 (= P. R. Dugan 115; Dugan et al., 1992; Friedman \& Dugan, 1968; Joyce \& Dugan, 1970). The $Z$. ramigera type strain ATCC $19544^{\mathrm{T}}$ and strain ATCC 19623 are known to be different (Rosselló-Mora et al., 1993; Shin et al., 1993)

Published online ahead of print on 21 October 2005 as DOI 10.1099/ ijs.0.63942-0.

Abbreviation: UASB, upflow anaerobic sludge blanket.

The GenBank/EMBL/DDBJ accession number for the 16S rRNA gene sequence of strain $\mathrm{ChO6}^{\top}$ is AY995149. and the third strain has been reclassified as the type strain of Duganella zoogloeoides (Hiraishi et al., 1997).

In this study, we report the results of a taxonomic examination of a newly isolated novel strain, $\mathrm{Ch}_{06}{ }^{\mathrm{T}}$, and of strain ATCC 19623.

For the isolation of aerobic bacteria, brownish-black granules (around $2 \mathrm{~mm}$ in diameter) from a brewery wastewatertreating UASB reactor, which had been operated anaerobically for 2 years, were homogenized by using an Ace homogenizer (Nihonseiki). The suspension was spread on R2A agar plates (Difco) after being serially diluted with $50 \mathrm{mM}$ phosphate buffer $(\mathrm{pH} 7 \cdot 0)$. The plates were incubated at $30^{\circ} \mathrm{C}$ for 2 weeks. Single colonies on the plates were purified by transferring them onto new plates and incubating them again under the same conditions. The purified colonies were tentatively identified by partial $16 \mathrm{~S}$ rRNA gene sequences. Strain $\mathrm{Ch} 6^{\mathrm{T}}$ was one of the isolates that appeared dominantly on the plates under aerobic conditions. After primary isolation and purification on R2A agar plates (Difco), strains were cultivated at $30^{\circ} \mathrm{C}$ on the same medium and stored at $-70{ }^{\circ} \mathrm{C}$ in R2A broth supplemented with $20 \%(\mathrm{v} / \mathrm{v})$ glycerol.

Extraction of genomic DNA, PCR-mediated amplification of the 16S rRNA gene and sequencing of the purified PCR product were carried out according to Kim et al. (2005). The 16S rRNA gene sequences of related taxa were obtained from GenBank. Multiple alignments were performed using the 


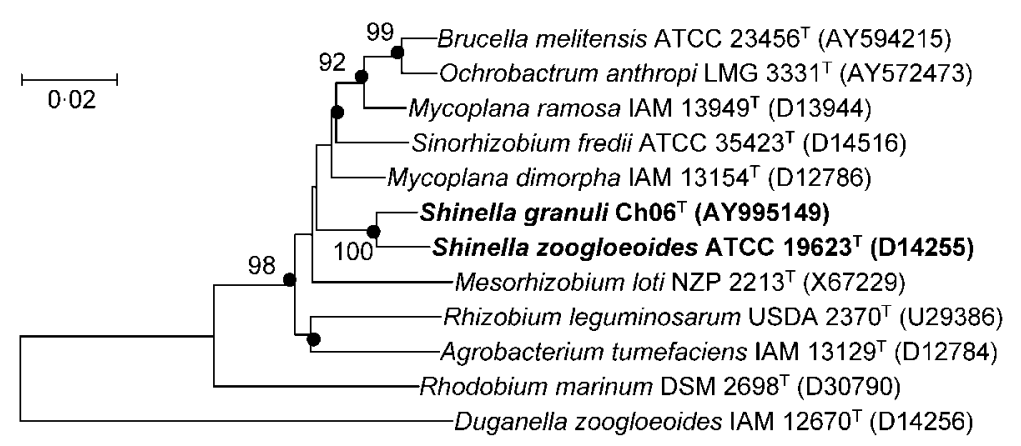

Fig. 1. Rooted phylogenetic tree based on the 16S rRNA gene sequences of strain $\mathrm{Ch06}^{\top}$ and related bacteria in the Alphaproteobacteria. This tree was constructed using the neighbour-joining method (Saitou \& Nei, 1987) with a Kimura (1983) twoparameter distance matrix and pairwise deletion. Dots indicate generic branches that were also recovered by using maximum-parsimony algorithms. Bootstrap values (expressed as percentages of 1000 replications) greater than $70 \%$ are shown at the branch points. Bar, 0.02 substitutions per nucleotide position.
CLUSTAL_X program (Thompson et al., 1997). Gaps were edited in the BioEdit program (Hall, 1999). Evolutionary distances were calculated using the Kimura two-parameter model (Kimura, 1983). Phylogenetic trees were constructed using the neighbour-joining (Saitou \& Nei, 1987) and maximum-parsimony (Fitch, 1971) methods using the MEGA3 program (Kumar et al., 2004) with bootstrap values based on 1000 replications (Felsenstein, 1985).

Phylogenetic 16S rRNA gene sequence analyses indicated that strain $\mathrm{Ch} 06^{\mathrm{T}}$ is a member of the family Rhizobiaceae and forms a distinct cluster with strain ATCC 19623 (Fig. 1). Genomic DNA of strain $\mathrm{Ch} 6^{\mathrm{T}}$ was extracted and purified with the Qiagen genomic-tip system 100/G and was enzymically degraded into nucleosides as described by Mesbah et al. (1989). The DNA G +C content was determined as described by Mesbah et al. (1989) using a reverse-phase HPLC. The DNA G + C content of strain $\mathrm{Ch} 06^{\mathrm{T}}$ was $66 \mathrm{~mol} \%$. DNA-DNA hybridization was performed fluorometrically by the method of Ezaki et al. (1989) using photobiotinlabelled DNA probes and microdilution wells. The level of DNA-DNA relatedness between strains $\mathrm{Ch} 6^{\mathrm{T}}$ and ATCC 19623 was $33 \%$, suggesting that the strains are different at the species level (Wayne et al., 1987; Stackebrandt \& Goebel, 1994).

The cellular fatty acids of strain $\mathrm{Ch} 06^{\mathrm{T}}$, grown on trypticase soy agar (Difco) for $48 \mathrm{~h}$, were saponified, methylated, extracted and identified by the Microbial Identification software package (Sasser, 1990). The major fatty acids of strain $\mathrm{Ch}_{06}{ }^{\mathrm{T}}$ were $\mathrm{C}_{16: 0}(9 \cdot 8-10 \cdot 4 \%), 3-\mathrm{OH} \mathrm{C} \mathrm{C}_{16: 0}(1 \cdot 6-$ $2 \cdot 2 \%), \mathrm{C}_{18: 0}(1 \cdot 6-2 \cdot 6 \%), \mathrm{C}_{19: 0}$ cyclo $\omega 8 \mathrm{c}(3 \cdot 0-4 \cdot 9 \%)$ and summed feature $7 \quad\left(75 \cdot 8-76.9 \% ; \quad \mathrm{C}_{18: 1} \omega 7 c / \omega 9 t / \omega 12 t\right.$, $\mathrm{C}_{18: 1} \omega 7 \mathrm{c} / \omega 9 \mathrm{cl}(\omega 12 t)$, showing a similar pattern to those of strain ATCC 19623, except for the presence of summed feature $3\left(\mathrm{C}_{16: 1} \omega 7 c / 15: 0\right.$ iso $\left.2-\mathrm{OH}\right)$ (Table 1$)$. Respiratory lipoquinones were analysed as described previously (Komagata \& Suzuki, 1987); the major respiratory lipoquinone was ubiquinone-10 (Q-10).

Cell morphology and motility were observed under a Nikon light microscope $(\times 1000$ magnification $)$ with cells grown on R2A agar for 3 days at $28^{\circ} \mathrm{C}$. The presence of flagella was determined by transmission electron microscopy (JEM10111; JEOL) after negative staining with uranyl acetate. Catalase activity was determined by bubble production in $3 \%(\mathrm{v} / \mathrm{v}) \mathrm{H}_{2} \mathrm{O}_{2}$ and oxidase activity was determined using $1 \%(\mathrm{w} / \mathrm{v})$ tetramethyl $p$-phenylenediamine. Growth at different temperatures and $\mathrm{pH}$ was assessed after 5 days incubation. Salt tolerance was tested on R2A medium supplemented with $1-10 \%(\mathrm{w} / \mathrm{v}) \mathrm{NaCl}$ after 5 days incubation. Growth was determined by monitoring the $\mathrm{OD}_{600}$. Anaerobic growth was observed in serum bottles by adding thioglycolate $\left(1 \mathrm{~g} \mathrm{l}^{-1}\right)$ to R2A broth and substituting the upper air layer with nitrogen gas. Substrate utilization as the sole carbon source and some physiological characteristics were determined with API 32GN and API 20NE galleries according to the manufacturer's instructions (bioMérieux).

Table 1. Cellular fatty acid profiles of strain $\mathrm{ChO6}^{\top}$ and type strains of related species

Species: 1, Shinella granuli sp. nov.; 2, Shinella zoogloeoides sp. nov.; 3, Mycoplana dimorpha; 4, Sinorhizobium fredii (data from Tighe et al., 2000); 5, Ochrobactrum anthropi (Trujillo et al., 2005). Fatty acids that account for $<1.5 \%$ of the total are not shown.

\begin{tabular}{|lccccc|}
\hline Fatty acid & $\mathbf{1}$ & $\mathbf{2}$ & $\mathbf{3}$ & $\mathbf{4}$ & $\mathbf{5}$ \\
\hline $16: 0$ & $9 \cdot 8-10 \cdot 4$ & $13 \cdot 4$ & $6 \cdot 2$ & $5 \cdot 12$ & $7 \cdot 2$ \\
$16: 0$ 3-OH & $1 \cdot 6-2 \cdot 2$ & $8 \cdot 1$ & - & - & - \\
$17: 0$ & - & - & $3 \cdot 1$ & - & $1 \cdot 6$ \\
$18: 0$ & $1 \cdot 6-2 \cdot 6$ & $2 \cdot 6$ & $7 \cdot 5$ & $4 \cdot 99$ & $5 \cdot 2$ \\
$18: 1$ 2-OH & - & - & - & - & $2 \cdot 4$ \\
$19: 0$ cyclo $\omega 8 \mathrm{c}$ & $3 \cdot 0-4 \cdot 9$ & $2 \cdot 9$ & $3 \cdot 5$ & $4 \cdot 37$ & $14 \cdot 5$ \\
$20: 3 \omega 6,9,12 c$ & - & - & - & $3 \cdot 28$ & - \\
Summed feature $2^{*}$ & - & - & - & - & $1 \cdot 6$ \\
Summed feature $3^{*}$ & $4 \cdot 4-5 \cdot 5$ & - & $3 \cdot 8$ & $7 \cdot 62$ & $2 \cdot 1$ \\
Summed feature $7^{*}$ & $75 \cdot 8-76 \cdot 9$ & $72 \cdot 9$ & $76 \cdot 1$ & $71 \cdot 45$ & $62 \cdot 8$ \\
\hline
\end{tabular}

* Summed features are groups of two or three fatty acids that cannot be separated by GLC with the MIDI system. Summed feature 2: 12:0 unknown aldehyde with ECL 10.928/16:1 iso I/14:0 3-OH. Summed feature 3: $16: 1 \omega 7 c / 15: 0$ iso $2-\mathrm{OH}$. Summed feature 7 : $18: 1 \omega 7 c / \omega 9 t / \omega 12 t, 18: 1 \omega 7 c / \omega 9 c / \omega 12 t$. 
Nitrate and nitrite reduction were confirmed by inoculating each strain into three $25 \mathrm{ml}$ serum bottles containing $13 \mathrm{ml}$ $\mathrm{R} 2 \mathrm{~A}$ medium. Nitrate and nitrite were added as $\mathrm{KNO}_{3}$ and $\mathrm{NaNO}_{2}$ at concentrations of $10 \mathrm{mM}$. The reduction of nitrate and nitrite was monitored by an ion chromatograph (790 personal IC; Metrohm) equipped with a conductivity detector and an anion exchange column (Metrosep Anion Supp 4; Metrohm). Nitrogen-fixing ability was determined by growth in $50 \mathrm{ml}$ of a nitrogen-free medium (DSMZ medium no. 3) contained in a $500 \mathrm{ml}$ Erlenmeyer flask. The primer system PolF-PolR (Poly et al., 2001) was used to amplify a nifH gene as described by Im et al. (2004). DNA degradation [using DNA agar (Difco) supplemented with $0.01 \%$ toluidine blue (Merck)], casein, cellulose and starch degradation (Atlas, 1993), lipid degradation (Kouker \&
Jaeger, 1987) and xylan degradation (Ten et al., 2004) were also investigated; reactions were read after 5 days. Duplicate antibiotic sensitivity tests were performed using filter paper discs containing the following: streptomycin $(5,10$ and $\left.15 \mu \mathrm{g} \mathrm{ml}^{-1}\right)$, tetracycline $\left(5,10\right.$ and $\left.15 \mu \mathrm{g}^{-1}\right)$, kanamycin $\left(1 \cdot 0,1 \cdot 5\right.$ and $\left.2 \cdot 0 \mathrm{mg} \mathrm{ml}^{-1}\right)$ and ampicillin $(20,25$ and $30 \mu \mathrm{g} \mathrm{ml}^{-1}$ ) (Sigma). Discs were placed on R2A plates spread with $\mathrm{Ch} 06^{\mathrm{T}}$ culture and then incubated at $28^{\circ} \mathrm{C}$ for 5 days.

Physiological, biochemical and morphological characteristics of the strains studied are listed under the species descriptions and are also given in Table 2. Phenotypic and chemotaxonomic examination shows that strains $\mathrm{Ch} 6^{\mathrm{T}}$ and ATCC 19623 share many common characteristics.

Table 2. Comparison of selected characteristics of Shinella granuli $\mathrm{Ch}^{\top} 6^{\top}$ with those of its nearest phylogenetic neighbours within the 'Rhizobiaceae group'

Species: 1, Shinella granuli sp. nov.; 2, Shinella zoogloeoides sp. nov.; 3, Mycoplana dimorpha; 4, Sinorhizobium fredii (data from de Lajudie et al., 1994; Wei et al., 2002; Willems et al., 2003; Young et al., 2001); 5, Ochrobactrum anthropi (de Lajudie et al., 1994; Lebuhn et al., 2000; Kämpfer et al., 2003; Trujillo et al., 2005). Data for taxa 1-3 are from this study. All strains were positive for assimilation of histidine, inositol, lactate, mannose, mannitol, proline and sorbitol and negative for assimilation of adipate, 3-hydroxybenzoate, suberate and phenylacetate and negative for gelatin hydrolysis. +, Positive; -, negative; w, weak.

\begin{tabular}{|c|c|c|c|c|c|}
\hline Characteristic & 1 & 2 & 3 & 4 & 5 \\
\hline Flagellation type & Polytrichous & $\begin{array}{l}\text { Mono- and } \\
\text { polytrichous }\end{array}$ & Peritrichous & $\begin{array}{l}\text { Subpolar or } \\
\text { peritrichous }\end{array}$ & $\begin{array}{l}\text { Subpolar or } \\
\text { peritrichous }\end{array}$ \\
\hline Nitrate reduction & + & - & - & $\mathrm{ND}$ & + \\
\hline \multicolumn{6}{|l|}{ Growth at: } \\
\hline $40{ }^{\circ} \mathrm{C}$ & + & - & - & - & ND \\
\hline $\mathrm{pH} 10$ & + & + & $\mathrm{W}$ & + & ND \\
\hline $4 \% \mathrm{NaCl}$ & + & - & + & - & ND \\
\hline$\beta$-D-Glucosidase & + & + & - & ND & - \\
\hline$\beta$-Galactosidase & + & + & - & ND & - \\
\hline Urease & + & - & - & - & + \\
\hline \multicolumn{6}{|l|}{ Growth on: } \\
\hline$N$-Acetylglucosamine & + & + & - & + & + \\
\hline Alanine & + & - & + & - & + \\
\hline Arabinose & + & + & - & + & + \\
\hline Fucose & + & + & - & + & + \\
\hline Gluconate & + & - & - & - & + \\
\hline 4-Hydroxybenzoate & + & - & - & ND & + \\
\hline 2-Ketogluconate & - & - & + & - & + \\
\hline Malate & + & - & - & + & + \\
\hline Maltose & + & + & - & + & + \\
\hline Propionate & + & + & - & - & + \\
\hline L-Rhamnose & + & + & - & + & + \\
\hline D-Ribose & + & + & - & - & + \\
\hline Salicin & + & - & - & - & - \\
\hline Sucrose & + & + & - & + & + \\
\hline Nitrogen fixation & - & - & - & + & ND \\
\hline $\begin{array}{l}\text { Mean DNA G }+ \text { C content } \\
(\mathrm{mol} \%)\end{array}$ & 66 & 64 & $63-68$ & 62 & $56-59$ \\
\hline
\end{tabular}


However, the strains differ with respect to nitrate reduction, growth at $40{ }^{\circ} \mathrm{C}$, growth at $4 \% \mathrm{NaCl}$, urease activity and their ability to assimilate carbon sources such as alanine, gluconate, 4-hydroxybenzoate, malate and salicin. Finally, the DNA-DNA relatedness value between the strains is low enough to differentiate them as separate species.

Phylogenetically, the two strains form a novel lineage of descent within the Alphaproteobacteria which is clustered with Mycoplana dimorpha IAM $13154^{\mathrm{T}}(96 \cdot 1-96 \cdot 3 \%$ similarity in 16S rRNA gene sequence) and Sinorhizobium fredii ATCC $35423^{\mathrm{T}}(95 \cdot 2-95 \cdot 5 \%$ similarity). The phylogenetic divergence and low level of similarity between 16S rRNA gene sequences support the affiliation of strains $\mathrm{Ch}^{\mathrm{T}}{ }^{\mathrm{T}}$ and ATCC 19623 into a novel genus. This is also supported by phenotypic and chemotaxonomic characteristics (Tables 1 and 2). The two strains can be differentiated from $\mathrm{Myco-}$ plana dimorpha IAM $13154^{\mathrm{T}}$ by $\beta$-glucosidase and $\beta$ galactosidase activity and the ability to assimilate arabinose, fucose, 2-ketogluconate, maltose, $N$-acetylglucosamine, propionate, L-rhamnose, D-ribose and sucrose. The hydroxy fatty acid identified for the two strains was $3-\mathrm{OH} \mathrm{C}_{16: 0}$, which is a unique profile of the proposed new genus Shinella gen. nov., and different from those of other genera such as Mycoplana, Sinorhizobium and Ochrobactrum (Table 1). It is noted that, in some cases, this hydroxyl fatty acid is important for discriminating between genera, for example Sinorhizobium and Rhizobium (Tighe et al., 2000). Moreover, the absence of cellular fatty acid $\mathrm{C}_{17: 0}$ also makes the genus Shinella different from the genera Mycoplana and Ochrobactrum (Table 1). Strains Ch06 ${ }^{\mathrm{T}}$ and ATCC 19623 can be differentiated from Sinorhizobium fredii ATCC $35423^{\mathrm{T}}$ by nitrogen fixation and the ability to assimilate $\mathrm{D}$-ribose and propionate. The DNA G $+\mathrm{C}$ content of strains $\mathrm{Ch}^{\mathrm{T}} 6^{\mathrm{T}}$ and ATCC 19623 was 2-4 mol\% higher than that of Sinorhizobium (Table 2). Moreover, strains $\mathrm{Ch}^{\mathrm{T}}{ }^{\mathrm{T}}$ and ATCC 19623 can be differentiated from Ochrobactrum anthropi LMG $3331^{\mathrm{T}}$ by their relatively low DNA G $+\mathrm{C}$ content and by their phenotypic and chemotaxonomic features (Tables 1 and 2). On the basis of morphological, phylogenetic, chemotaxonomic and physiological data, we propose that strain $\mathrm{Ch}^{\mathrm{T}} \mathrm{6}^{\mathrm{T}}$ is a member of a novel genus and species, Shinella granuli gen. nov., sp. nov. In addition, we propose the reclassification of Zoogloea ramigera ATCC 19623 to the genus Shinella as Shinella zoogloeoides sp. nov.

\section{Description of Shinella gen. nov.}

Shinella (Shi.nel'la. N.L. fem. dim. n. Shinella named after Yong-Kook Shin, for his contributions to reclassification of the genus Zoogloea).

Cells are Gram-negative, non-spore-forming, motile rods. Amorphous or finger-like flocculent growth occurs in liquid media. Catalase-, oxidase-, $\beta$-galactosidase- and $\beta$-glucosidasepositive. Predominant cellular fatty acids are $\mathrm{C}_{16: 0}$ and summed feature $7 \quad\left(\mathrm{C}_{18: 1} \omega 7 c / \omega 9 t / \omega 12 t, \mathrm{C}_{18: 1} \omega 7 c / \omega 9 c /\right.$ $\omega 12 t)$ and $\mathrm{C}_{16: 0} 3-\mathrm{OH}$ is the predominant hydroxy fatty acid. The main lipoquinone is $\mathrm{Q}-10$. DNA G $+\mathrm{C}$ content is
64-66 mol\%. 16S rRNA gene sequence analysis indicates that the genus Shinella is a member of the family Rhizobiaceae of the Alphaproteobacteria. The type species is Shinella granuli.

\section{Description of Shinella granuli sp. nov.}

Shinella granuli (gra.nu'li. L. gen. n. granuli of a small grain, pertaining to a granule, from which the type strain was isolated).

Characteristics are as given for the genus. In addition, cells are $0 \cdot 2-0.5 \mu \mathrm{m}$ in width and $4-6 \mu \mathrm{m}$ in length. Motile by means of multiple polar flagella (Fig. 2). Colonies on R2A agar media are glistening, convex with an entire margin, viscous and pale-yellow. Growth occurs at $4-40{ }^{\circ} \mathrm{C}$, with $1-4 \% \mathrm{NaCl}$ and at $\mathrm{pH} 6-10$. Nitrogen fixation is negative. Does not hydrolyse starch, cellulose, xylan, protein, lipid, casein, gelatin or DNA. Does not utilize adipate, arginine, caparate, citrate, glycogen, 3-hydroxybenzoate, itaconate, 2-ketogluconate, 5-ketogluconate, malonate, melibiose, phenylacetate, suberate or valerate as sole carbon sources. Resistant to $50 \mu \mathrm{g}$ ampicillin $\mathrm{ml}^{-1}$ and $15 \mu \mathrm{g}$ tetracycline $\mathrm{ml}^{-1}$, but sensitive to $5 \mu \mathrm{g}$ streptomycin $\mathrm{ml}^{-1}$ and $1 \mathrm{mg}$ kanamycin $\mathrm{ml}^{-1}$. The predominant cellular fatty acids are $\mathrm{C}_{16: 0}(9 \cdot 8-10 \cdot 4 \%), 3-\mathrm{OH} \mathrm{C} \mathrm{C}_{16: 0}(1 \cdot 6-2 \cdot 2 \%), \mathrm{C}_{18: 0}(1 \cdot 6-$ $2 \cdot 6 \%), \mathrm{C}_{19: 0}$ cyclo $\omega 8 c(3 \cdot 0-4 \cdot 9 \%)$ and summed feature 7 $\left(75 \cdot 8-76 \cdot 9 \% ; \quad \mathrm{C}_{18: 1} \omega 7 c / \omega 9 t / \omega 12 t, \quad \mathrm{C}_{18: 1} \omega 7 c / \omega 9 c / \omega 12 t\right)$. The major respiratory quinone is $\mathrm{Q}-10$. DNA G $+\mathrm{C}$ content is $66 \mathrm{~mol} \%$.

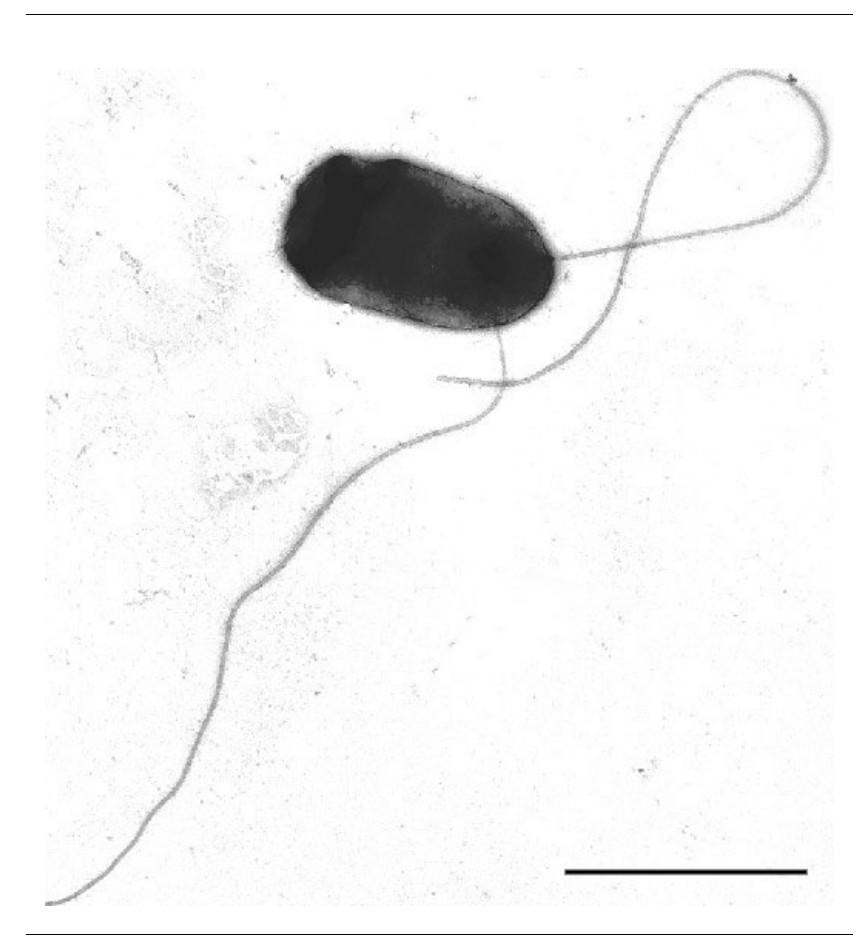

Fig. 2. Transmission electron micrograph of a motile cell of Shinella granuli $\mathrm{Ch06}^{\top}$. Bar, $1 \mu \mathrm{m}$. 
The type strain, $\mathrm{Ch}_{06} 6^{\mathrm{T}}\left(=\mathrm{KCTC} 12237^{\mathrm{T}}=\mathrm{JCM} 13254^{\mathrm{T}}\right)$, was isolated from a UASB reactor.

\section{Description of Shinella zoogloeoides sp. nov.}

Shinella zoogloeoides (zoo.gloe.o'i.des. N.L. n. Zoogloea bacterial genus name; Gr. suff. -oides similar to; N.L. adj. zoogloeoides similar to Zoogloea).

The description is as given for the genus and by Shin et al. (1993) and Rosselló-Mora et al. (1993), with the addition that it is negative in tests for amylase, protease, lipase, cellulose, xylanase, DNase, gelatinase and urease. Nitrogen fixation is negative. Does not utilize adipate, alanine, arginine, caparate, citrate, glycogen, gluconate, 3-hydroxybenzoate, 4-hydroxybenzoate, itaconate, 2-ketogluconate, 5-ketogluconate, malate, malonate, melibiose, phenylacetate, salicin, suberate or valerate. The predominant cellular fatty acids are $\mathrm{C}_{16: 0}(13 \cdot 4 \%), 3-\mathrm{OH} \mathrm{C}_{16: 0}(8 \cdot 1 \%), \mathrm{C}_{18: 0}(2 \cdot 6 \%), \mathrm{C}_{19: 0}$ cyclo $\omega 8 c(2 \cdot 9 \%)$ and summed feature $7\left(72 \cdot 9 \% ; \mathrm{C}_{18: 1} \omega 7 \mathrm{cl}\right.$ $\left.\omega 9 t / \omega 12 t, \quad C_{18: 1} \omega 7 c / \omega 9 c / \omega 12 t\right)$. The major respiratory quinone is $\mathrm{Q}-10$. DNA G $+\mathrm{C}$ content is $64 \mathrm{~mol} \%$.

The type strain, ATCC $19623^{\mathrm{T}}\left(=\mathrm{IAM} 12669^{\mathrm{T}}=\mathrm{I}-16-\mathrm{M}^{\mathrm{T}}\right)$, was isolated from sewage treatment systems.

\section{Acknowledgements}

This work was supported by the 21C Frontier Microbial Genomics and Application Center Program, Ministry of Science \& Technology (grant MG05-0101-4-0) and by Eco-Tecnopia-21, Ministry of Environment, Republic of Korea.

\section{References}

Atlas, R. M. (1993). Handbook of Microbiological Media. Edited by L. C. Parks. Boca Raton, FL: CRC Press.

Bae, H.-S., Im, W.-T. \& Lee, S.-T. (2005). Lysobacter concretionis sp. nov., isolated from anaerobic granules in an upflow anaerobic sludge blanket reactor. Int J Syst Evol Microbiol 55, 1155-1161.

Crabtree, K. \& McCoy, E. (1967). Zoogloea ramigera Itzigsohn, identification and description. Request for an Opinion as to the status of the generic name Zoogloea. Int J Syst Bacteriol 17, 1-10.

de Lajudie, P., Willems, A., Pot, B. \& 7 other authors (1994). Polyphasic taxonomy of Rhizobia: emendation of the genus Sinorhizobium and description of Sinorhizobium meliloti comb. nov., Sinorhizobium saheli sp. nov., and Sinorhizobium teranga sp. nov. Int J Syst Bacteriol 44, 715-733.

Dugan, P. R., Stoner, D. L. \& Pickrum, H. M. (1992). The genus Zoogloea. In The Prokaryotes, 2nd edn, pp. 3952-3964. Edited by A. Balows, H. G. Trüper, M. Dworkin, W. Harder \& K.-H. Schleifer. New York: Springer.

Ezaki, T., Hashimoto, Y. \& Yabuuchi, E. (1989). Fluorometric deoxyribonucleic acid-deoxyribonucleic acid hybridization in microdilution wells as an alternative to membrane filter hybridization in which radioisotopes are used to determine genetic relatedness among bacterial strains. Int J Syst Bacteriol 39, 224-229.

Felsenstein, J. (1985). Confidence limits on phylogenies: an approach using the bootstrap. Evolution 39, 783-791.
Fitch, W. M. (1971). Toward defining the course of evolution: minimum change for a specific tree topology. Syst Zool 20, 406-416.

Friedman, B. A. \& Dugan, P. R. (1968). Identification of Zoogloea species and the relationship to zoogloeal matrix and floc formation. J Bacteriol 95, 1903-1909.

Hall, T. A. (1999). BIOEDIT: a user-friendly biological sequence alignment editor and analysis program for Windows 95/98/NT. Nucleic Acids Symp Ser 41, 95-98.

Hiraishi, A., Shin, Y. K. \& Sugiyama, J. (1997). Proposal to reclassify Zoogloea ramigera IAM 12670 (P. R. Dugan 115) as Duganella zoogloeoides gen. nov., sp. nov. Int J Syst Bacteriol 47, 1249-1252.

Im, W.-T., Bae, H.-S., Yokota, A. \& Lee, S. T. (2004). Herbaspirillum chlorophenolicum sp. nov., a 4-chlorophenol-degrading bacterium. Int J Syst Evol Microbiol 54, 851-855.

Joyce, G. H. \& Dugan, P. R. (1970). The role of floc-forming bacteria in BOD removal from wastewater. Dev Ind Microbiol 11, 377-386.

Kämpfer, P., Buczolits, S., Albrecht, A., Busse, H.-J. \& Stackebrandt, E. (2003). Towards a standardized format for the description of a novel species (of an established genus): Ochrobactrum gallinifaecis sp. nov. Int J Syst Evol Microbiol 53, 893-896.

Kim, M. K., Im, W.-T., Ohta, H., Lee, M. \& Lee, S.-T. (2005). Sphingopyxis granuli sp. nov., a $\beta$-glucosidase-producing bacterium in the family Sphingomonadaceae in $\alpha-4$ subclass of the Proteobacteria. J Microbiol 43, 152-157.

Kimura, M. (1983). The Neutral Theory of Molecular Evolution, pp. 41-46. Cambridge: Cambridge University Press.

Komagata, K. \& Suzuki, K. (1987). Lipid and cell wall analysis in bacterial systematics. Methods Microbiol 19, 161-207.

Kouker, G. \& Jaeger, K.-E. (1987). Specific and sensitive plate assay for bacterial lipases. Appl Environ Microbiol 53, 211-213.

Kumar, S., Tamura, K. \& Nei, M. (2004). MEGA3: Integrated software for molecular evolutionary genetics analysis and sequence alignment. Brief Bioinform 5, 150-163.

La, H.-J., Im, W.-T., Ten, L. N., Kang, M.-S., Shin, D.-Y. \& Lee, S.-T. (2005). Paracoccus koreensis sp. nov., isolated from anaerobic granules in an upflow anaerobic sludge blanket (UASB) reactor. Int J Syst Evol Microbiol 55, 1657-1660.

Lebuhn, M., Achouak, W., Schloter, M., Berge, O., Meier, H., Barakat, M., Hartmann, A. \& Heulin, T. (2000). Taxonomic characterization of Ochrobactrum sp. isolates from soil samples and wheat roots, and description of Ochrobactrum tritici sp. nov. and Ochrobactrum grignonense sp. nov. Int J Syst Evol Microbiol 50, 2207-2223.

Mesbah, M., Premachandran, U. \& Whitman, W. B. (1989). Precise measurement of the $\mathrm{G}+\mathrm{C}$ content of deoxyribonucleic acid by highperformance liquid chromatography. Int J Syst Bacteriol 39, 159-167.

Poly, F., Monrozier, L. J. \& Bally, R. (2001). Improvement in the RFLP procedure for studying the diversity of nifH genes in communities of nitrogen fixers in soil. Res Microbiol 152, 95-103.

Rosselló-Mora, R. A., Ludwig, W. \& Schleifer, K. H. (1993). Zoogloea ramigera: a phylogenetically diverse species. FEMS Microbiol Lett 114, 129-134.

Saitou, N. \& Nei, M. (1987). The neighbor-joining method: a new method for reconstructing phylogenetic trees. Mol Biol Evol 4, 406-425.

Sasser, M. (1990). Identification of Bacteria by Gas Chromatography of Cellular Fatty Acids. MIDI Technical Note 101. Newark, DE: MIDI Inc.

Shin, Y. K., Hiraishi, A. \& Sugiyama, J. (1993). Molecular systematics of the genus Zoogloea and emendation of the genus. Int $J$ Syst Bacteriol 43, 826-831. 
Stackebrandt, E. \& Goebel, B. M. (1994). Taxonomic note: a place for DNA-DNA reassociation and 16S rRNA sequence analysis in the present species definition in bacteriology. Int J Syst Bacteriol 44, 846-849.

Ten, L. N., Im, W.-T., Kim, M.-K., Kang, M.-S. \& Lee, S.-T. (2004). Development of a plate technique for screening of polysaccharidedegrading microorganisms by using a mixture of insoluble chromogenic substrates. J Microbiol Methods 56, 375-382.

Thompson, J. D., Gibson, T. J., Plewniak, F., Jeanmougin, F. \& Higgins, D. G. (1997). The CLUSTAL_X windows interface: flexible strategies for multiple sequence alignment aided by quality analysis tools. Nucleic Acids Res 25, 4876-4882.

Tighe, S. W., de Lajudie, P., Dipietro, K., Lindström, K., Nick, G. \& Jarvis, B. D. W. (2000). Analysis of cellular fatty acids and phenotypic relationships of Agrobacterium, Bradyrhizobium, Mesorhizobium, Rhizobium and Sinorhizobium species using the Sherlock Microbial Identification System. Int J Syst Evol Microbiol 50, 787-801.

Trujillo, M. E., Willems, A., Abril, A., Planchuelo, A. M., Rivas, R., Ludeña, D., Mateos, P. F., Martínez-Molina, E. \& Velázquez, E. (2005). Nodulation of Lupinus albus by strains of Ochrobactrum lupini sp. nov. Appl Environ Microbiol 71, 1318-1327.

Unz, R. F. (1971). Neotype strain of Zoogloea ramigera Itzigsohn. Request for an Opinion. Int J Syst Bacteriol 21, 91-99.
Unz, R. F. (1984). Genus IV. Zoogloea Itzigsohn 1868, 30 ${ }^{\mathrm{AL}}$. In Bergey's Manual of Systematic Bacteriology, vol. 1, pp. 214-219. Edited by N. R. Krieg \& J. G. Holt. Baltimore: Williams \& Wilkins.

Wayne, L. G., Brenner, D. J., Colwell, R. R. \& 9 other authors (1987). International Committee on Systematic Bacteriology. Report of the ad hoc committee on reconciliation of approaches to bacterial systematics. Int J Syst Bacteriol 37, 463-464.

Wei, G. H., Wang, E. T., Tan, Z. Y., Zhu, M. E. \& Chen, W. X. (2002) Rhizobium indigoferae sp. nov. and Sinorhizobium kummerowiae sp. nov., respectively isolated from Indigofera spp. and Kummerowia stipulacea. Int J Syst Evol Microbiol 52, 2231-2239.

Willems, A., Fernández-López, M., Muñoz-Adelantado, E., Goris, J., De Vos, P., Martínez-Romero, E., Toro, N. \& Gillis, M. (2003). Description of new Ensifer strains from nodules and proposal to transfer Ensifer adhaerens Casida 1982 to Sinorhizobium as Sinorhizobium adhaerens comb. nov. Request for an Opinion. Int J Syst Evol Microbiol 53, 1207-1217.

Young, J. M., Kuykendall, L. D., Martínez-Romero, E., Kerr, A. \& Sawada, H. (2001). A revision of Rhizobium Frank 1889, with an emended description of the genus, and the inclusion of all species of Agrobacterium Conn 1942 and Allorhizobium undicola de Lajudie et al. 1998 as new combinations: Rhizobium radiobacter, R. rhizogenes, R. rubi, R. undicola and R. vitis. Int J Syst Evol Microbiol 51, 89-103. 